\title{
Changes in the Number and Formation of Lumbar Vertebrae in the European Bison
}

\author{
Zmiany w liczebności i ukształtowaniu kręgów lędźwiowych żubra
}

\author{
Henryk KOBRYÑ \& Franciszek KOBRYNCZUK
}

\begin{abstract}
Kobryń H. \& Kobryńczuk F., 1976: Changes in the number and formation of lumbar vertebrae in the European bison. Acta theriol., 21, 11: 172-173. [With Plate III].

The authors found that there were six lumbar vertebrae present in a 12-year old male bison, and that the last of these vertebrae had undergone sacralization. The number of thoracic vertebrae remained unchanged.
\end{abstract}

[Inst. Anim. Physiol., Agric. Acad., 03-849 Warszawa, Grochowska 272, Poland].

Studies on the spinal column of the European bison, Bison bonasus L in n a e us, 1758, have shown that cases may occur of deviations from the typical number of vertebrae in different parts of the spine $(\mathrm{J}$ a $\mathrm{nic} \mathrm{ki}$, 1938; J u śk o, 1953; Pil a r ski \& R os k os z, 1957; R os k os z, 1962; R osk os z, 1973; K obr yń, 1973).

Pars lumbalis of the spinal column consists of five vertebrae in the majority of European bison, but exceptional cases have been observed of there being four, or more rarely, six vertebrae. In the first case the final (fifth) lumbar vertebra, during the process of sacralization, fused with the sacral vertebrae, forming with them one os sacrum, and in consequence the lumbar part of the spine is formed of only four, and the sacral part of six vertebrae.

An increase in the number of lumbar vertebrae from five to six usually takes place at the expence of the final (fourteenth) thoracic vertebra, which becomes decidedly similar to the lumbar vertebrae. This phenomenon, termed lumbalization, involves reduction in the number of thoracic vertebrae from 14 to 13 . In both cases, therefore, these deviations only take the form of shifts in the number of vertebrae in the neighbouring parts of the spine.

The authors had the opportunity of seeing a case in which there were six lumbar vertebrae, the last of which had undergone sacralization. It must, however, be emphasised here that there were six lumbar vertebrae present with an unchanged number of thoracic vertebrae. A situation of this sort has not so far been reported in literature on the skeleton of the European bison.

The spine in question belonged to a 12-year old male bison from the herd living in a natural habitat in the Bieszczady Mountains. Breeding records and verbal information revealed that this bison had not exhibited any deviation from the normal during its lifetime. Among all the various parts of the spine, it is only the lumbar and sacral parts which exhibit the presence of certain deviations.

The lumbar part is formed here of six vertebrae, of which $L_{4}$ may be considered as a supernumerary unit, while $\mathrm{L}_{6}$ has undergone sacralization. The supernumerary vertebra does not, however, occur independently, but fuses with $\mathrm{L}_{3}$, forming with it a massive, assymetrical structure 


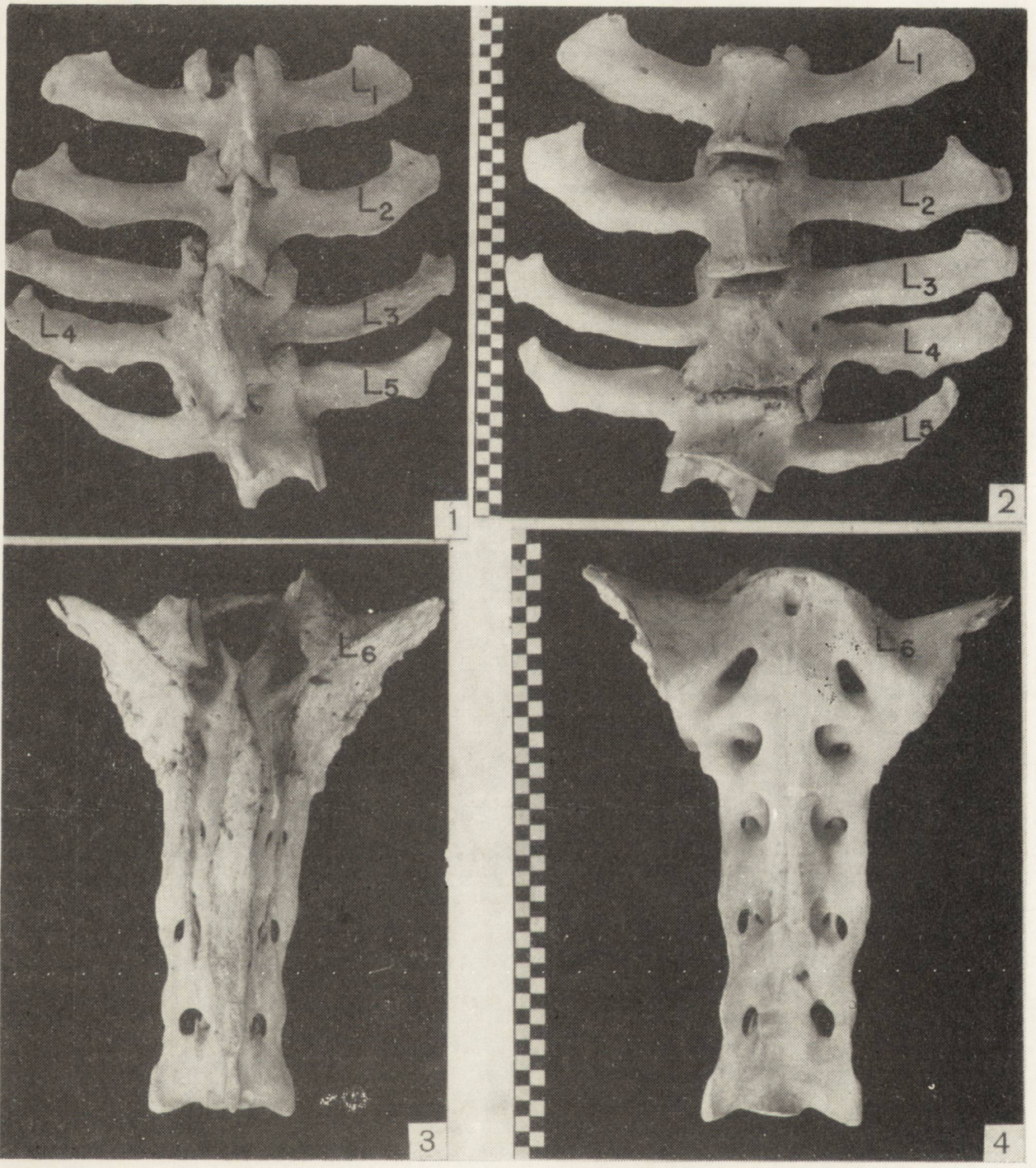

Upper row: Lumbar vertebrae, seen from dorsal (1) and ventral side (2). Bottom row: Os sacrum together with sixth lumbar vertebra, seen from dorsal (3) and ventral side (4).

H. Kobryń \& F. Kobryńczuk S. Pytel phot.

Wklejka pomiędzy str. $172 / 173$ 
(Figs 1,2 ). The supernumerary vertebra $L_{4}$ has only a well formed left transverse process which has retained its autonomy, a slightly more weakly developed shaft and arch and also left articular processes anterior and posterior (Fig. 1). There is, however, no right transverse process or right anterior articular process. The lumbar part, as a result, is distinctly curved as from $\mathrm{L}_{4}$ to the right side (Fig. 1).

$\mathrm{L}_{6}$ merits separate discussion, as it had become similar to the sacral vertebrae, completely fused with them, forming the sacral bone (Figs. 3, 4). Alae ossis sacri are thus to a great extent by correspondingly modified by transverse processes of $\mathrm{L}_{6}$.

The considerable curve of the lumbar part was appropriately compensated for by the assymetry of the sacral bone, resulting in the erected lumbar part and sacral bone forming a straight line, which affected the normal exterior appearance of the bison when alive.

It is difficult to find the reasons for increase in the number of lumbar vertebrae in the particular case. It may be connected with the phylogenesis of the spine, where with transition from lower vertebrates to higher ones and transfer of carrying function from the axial skeleton to the limbs, the number of vertebrae underwent reduction. The causes of this phenomenon could also be sought for in a certain "lack of perfection « in the process of secondary metamerization of the spine during ontogenesis. If, on the other hand, then this took place as the result of the vertebrae of neighbouring parts of the spine being subject to similar biomechanical factors, which led to their becoming similar to each other. It must continually be borne in mind that it is the sacral bone which participates in the connection of the axial skeleton with the girdle of the pelvic limbs. It is these limbs which decidedly supply the driving force and these forces must be transmitted to a sufficiently strong spinal column. It is also known ( $\mathrm{Kobryn} \mathrm{czuk}$, 1972) that the locomotor apparatus in the bison remains very effective up to the end of its life.

In turn, to which P o plew ski (1948) has already drawn attention, both during individual and family development, a shift forwards is found in the site at which the pelvic girdle is attached to the spine, and the final lumbar vertebra must take part in this process.

\section{REFERENCES}

J an icki S., 1938: Badania nad szkieletem żubra (Bison bonasus L.) P.A.U., Prace Roln.-Leśne, 27: 1-55. Kraków. J u śko J., 1953: Dimorfizm płciowy szkieletu żubra (Bison bonasus). Folia morphol., 1: 1-30. K o br y ń H., 1973: The thorax in European bison and other Ruminants. Acta theriol., 18, 17: 313-341. K o br y ńc zuk F., 1976: Joints and ligaments of hind-limbs of the European bison in their postnatal development. Acta theriol., 21, 1: 37-100. Pilarski W. \& Roskosz T., 1957: Zjawisko ukrzyżowania (sacralisatio) ostatniego kręgu lędźwiowego u samic żubra - Bison bonasus L. Folia morphol., 2: 109-119. P oplewski R., 1948: Anatomia ssaków. 2: 1-690. Spółdz. Wyd. Czytelnik. R oskosz T., 1962: Morphologie der Wirbelsäule des Wisents, Bison bonasus ( $\mathrm{L}$ in n a e u s, 1758). Acta theriol., 6, 5: 113-164. Roskosz T., 1973: Studium nad kanałem kręgowym (canalis vertebralis) żubra, Bison bonasus ( $\mathrm{L}$ in na e u s, 1758). Zeszyty Nauk. Akad. Roln., 29: $1-58$. 